\title{
Control of hepatic glyceride synthesis
}

By D. A. Hems, Department of Biochemistry, Imperial College of Science and Technology, London $\mathrm{SW}_{7} 2 \mathrm{AZ}$

\section{Role of the liver in glyceride metabolism}

In mammals, there are three major forms of circulating lipid or lipid-related fuel, free fatty acid (FFA), triglyceride (TG) and ketone bodies. The liver utilizes FFA, and releases TG and ketone bodies. Constituents of the pool of carbohydrate plus amino acids can undergo net conversion to acetyl residues and then to fatty acids (FA) (FA synthesis 'de novo') whereas the reverse process cannot occur. FA from all sources may be degraded, or incorporated into TG and other glycerides, for internal consumption or export. Aspects of hepatic lipid metabolism may alter in a variety of physiological and pathological states (e.g. diabetes and other endocrine disorders, vascular disease, nephrosis, shock, malnutrition, catabolic disease, obesity, inborn errors, liver disease). Despite the likelihood that such changes are of crucial pathogenetic significance, very little is known about the mechanisms underlying them, or indeed about the control of hepatic glyceride metabolism in normal animals.

\section{Pathways of hepatic glyceride synthesis}

Glycerides are synthesized from activated glycerol, in the form of $S n$-glycero-3phosphate (formed during glycolysis, gluconeogenesis, or from blood glycerol) and from activated FA, i.e. long-chain acyl-CoA. The FA in acyl-CoA may be synthesized de novo or derived from FFA, which are either taken up from plasma via a transport protein (Mishkin, Stein, Gatmaitan \& Arias, 1972), or produced by intra-hepatic lipolysis. Synthesis de novo of glyceride-FA in the liver involves a variety of precursors. In man, their nature, or even the occurrence of hepatic synthesis de novo of FA, is not established. In the mouse, glycogen and lactate are favoured carbon sources, whereas glucose is an unimportant precursor, as shown in the perfused liver (Salmon, Bowen \& Hems, 1974), and in vivo (Hems, Rath \& Verrinder, 1975). The major products of extra-mitochondrial synthesis de novo of FA are palmityl- and stearyl-CoA (Wadke, Brunengraber, Lowenstein, Dolhun \& Arsenault, I973), which can convert to other species of acyl-CoA. Newly-synthesized FA are incorporated mainly into hepatic phospholipids (PL) and TG. Hydrogen atoms enter newly-synthesized FA by various routes (Rous, I 971), which feature NADPH as the reducing-equivalent carrier. The ratio, free $\mathrm{NADP}^{+}$: free NADPH is increased in states where FA synthesis is enhanced, e.g. on carbohydrate-rich diets (Krebs \& Veech, 1969) or in obese mice (Elliott, Dade, Salmon \& Hems, 1974). Glucose, lactate and perhaps glycogen can all stimulate 
lipogenesis, independently of their role as C-sources (Salmon et al. r 974), perhaps through alterations in the events of reducing-equivalent transfer.

The central group of enzymes of glyceride synthesis is the acyltransferases, exhibiting complex substrate selectivities and responses to effectors (Lands, 1965; Abou-Issa \& Clelland, 1968; Reitz, Lands, Christie \& Holman, r968; Lamb \& Fallon, 1970; Fallon, Barwick, Lamb \& Van den Bosch, 1975; Okuyama, Yamada \& Ikezawa, 1975; Yamashita, Nakaya, Miki \& Numa, 1975) which are of prime importance in the control of the pattern of glycerides fashioned in the liver. This is illustrated by the preference, for example, of oleate to enter TG (Nakagawa \& Uchiyama, r 969; Topping \& Mayes, 1972) and of other FA to follow particular routes into glycerides (Akesson, 1970; Akesson, Elovson \& Arvidson, 1970). The hydrolysis of phosphatidic acids by a phosphatase (Hosaka, Yamashita \& Numa, I975) is also a critical branch-point in both TG and PL production, being ratecontrolling in, for example, the regenerating liver (Mangiapane, Lloyd-Davies \& Brindley, I973). In the instance of PL, base transfer is the last process in synthesis (Dawson, 1966).

\section{Subcellular location of steps of glyceride synthesis}

The major FA-activating enzymes are located in the endoplasmic reticulum and the outer mitochondrial membrane (Lippel, Robinson \& Trams, 1970; Groot, Van Loon \& Hulsmann, I974; Van Golde, Raben, Batenburg, Fleischer, Zambrano \& Fleischer, 1974) and in general are not rate-limiting in FA metabolism (LloydDavies \& Brindley, 1973). Thus acyl-CoA species are available in the extramitochondrial phase for incorporation into glycerides. The subsequent entry of FA into mitochondria occurs mainly by the carnitine acyltransferase system, comprising at least two enzymes (Solberg, 1974). This system is a major site of control of glyceride metabolism in liver (see McGarry \& Foster, 1972, 1974); thus $(+)$ decanoyl carnitine, an inhibitor, inhibits ketogenesis in livers from starved (McGarry, Meier \& Foster, 1973) or diabetic (McGarry \& Foster, 1973) animals, and restores diminished rates of glyceride synthesis. In liver, carnitine-independent FA oxidation can also be observed (van Tol \& Hulsmann, 1970).

Mitochondria possess a complement of enzymes for synthesis of glycerides, especially PL (Sarzala, Van Golde, de Kruyff \& van Deenen, 1970; Sanchez, Nicholls \& Brindley, 1973), although synthesis in the extramitochondrial phase is more extensive (Van Golde et al. 1974) and provides glycerides for mitochondria (Parkes \& Thompson, 1973).

The transfer of long-chain acyl substituents to glycerides, and to TG in particular, occurs mainly in the extramitochondrial phase, featuring microsomal enzymes. On the other hand, the FA synthetase complex appears in the supernatant fraction, during subcellular fractionation.

There are many subgroups of hepatic glycerides, of which the main ones are 'floating fat' (i.e. stored intracellular 'TG 'droplet': Di Augustine, Schaefer \& Fouts, 1973; Singer, Gnauck, Honigman, Stolz, Schliack, Kettler, Buntrock \& Thoelke, 1974), microsomal lipid (available for disposition throughout the cell), membrane lipids, and lipoprotein awaiting export. These lipids exhibit great variety of 
structure within the major classes (Wood \& Harlow, 1969; Kuksis, 1972; Sinclair, 1974). The functional roles of these differences are obscure.

\section{Interconversions among $F A$ and glycerides}

There is a variety of FA in lipids, each fulfilling its role, as do amino acids in proteins. In the liver, extensive interconversions among FA occur (see Fulco, 1974), featuring elongation (Seubert \& Podack, 1973) and desaturation (Gurr, 1974) reactions. The elongation systems in mitochondria (Podack, Lakomek, Saathoff \& Seubert, 1974; Hinsch \& Seubert, 1975) and the extra-mitochondrial phase (Stoffel \& Ach, 1964; Nugteren, 1965; Landriscina, Gnoni \& Quagliariello, 1970) which correspond in general to one 'turn' of the FA synthetase, achieve prominence in starvation (Coniglio \& Cate, 1958). The latter system has a major role in the conversions among polyunsaturated FA. It is not clear whether elongation from $\mathrm{C}_{16}$ to $\mathrm{C}_{18}$ is brought about by the synthetase complex, or by a separate system; the former seems more likely.

The desaturations among FA are widespread (Brett, Howling, Morris \& James, 1971) and complex, and include at least two major systems (Brenner, 1971; Gurr, 1974) which bind: (1) saturated acyl-CoA, inserting a cis double bond at $\Delta 9$; or (2) unsaturated acyl-CoA with a cis double bond at $\Delta 9$, (and perhaps other double bonds, towards the methyl group), inserting a cis double bond at $\Delta 6$. The major substrates for the $\Delta 9$-desaturase complex are palmityl- and stearyl-CoA (Gurr, 1974). This system comprises cytochrome $b_{5}$ and its reductase and oxidase (EC I.6.2.2) (Jones, Holloway, Peluffo \& Wakil, r969; Holloway \& Holloway, 1975); the latter component has been purified (Strittmatter, Spatz, Corcoran, Rogers, Setlow \& Redline, 1974) and has regulatory significance (Oshino \& Sato, 1972). The $\Delta 6$-desaturase participates in the interconversions among polyunsatured FA. In mammals, it appears that monoenoic-dienoic conversions, or desaturations at $\Delta_{3}, \Delta_{12}$ and $\Delta_{1} 5$ or other positions, do not occur. The desaturases exhibit diurnal rhythms (Actis-Dato, Catala \& Brenner, 1972) and decline on starvation (Elovson, 1965; Inkpen, Harris \& Quackenbush, 1969; De Gomes Dumm, De Alaniz \& Brenner, 1970; Oshino, 1972; Oshino \& Sato, 1972) or diabetes (De Tomas, Peluffo \& Mercuri, I973; Mercuri, Peluffo \& De Tomas, 1974) in parallel with FA synthetase (especially the $\Delta \boldsymbol{g}$-desaturase).

Hepatic acylglycerols and PL undergo extensive interconversions. Thus, the liver contains appropriate lyases for the degradation of PL (Gatt \& Barenholz, 1973) and TG (Kaplan \& Teng, I97r).

\section{Export of hepatic glycerides}

The liver is the major source of 'endogenous' (non-dietary) plasma lipoproteinglyceride, the FA of which exhibits rapid turnover in rodents (e.g. mice: Salmon \& Hems, 1973) if not man (Eaton, Berman \& Steinberg, 1969). Participation of the liver in lipoprotein dynamics is complex (Stein \& Stein, 1974). The major species exported is very-low-density lipoprotein (VLDL) the composition of which can be influenced by the blood FA pattern (Nestel \& Steinberg, 1963; Kohout, 
Kohoutova \& Heimberg, 1971; Heimberg \& Wilcox, 1972). VLDL is assembled in the Golgi complex (Chapman, Mills \& Taylaur, 1973) from mature glycerides synthesized largely on the endoplasmic reticulum. Biliary glycerides (mainly PL) are synthesized on endoplasmic reticulum (Gregory, Vlahcevic, Schatzki \& Swell, 1975). Apoprotein availability is critical in lipoprotein export. Both PL and droplet TG contribute FA for export in lipoprotein (Bar-On, Roheim, Stein \& Stein, 1971), rather than for degradation (Van Harken, Dixon \& Heimberg, 1969). Polyunsaturated FA are implicated in VLDL export (Fukazawa, Privett \& Takahashi, 1971).

\section{Hormonal control of glyceride synthesis}

Hormones are implicated in the regulation of hepatic glyceride synthesis and export, at every phase of these processes. Actions include stimulation of glyceride synthesis and secretion by insulin (Topping \& Mayes, 1972) and cortisol (Klausner \& Heimberg, 1967), and impairment in diabetes (Wilcox, Dishmon \& Heimberg, 1968; Balasse, Bier \& Havel, 1972; McGarry \& Foster, 1973). A permissive or facilitative action is exerted by adrenal steroids (Kirk, Verrinder \& Hems, I975) and by gonadal hormones (Weinstein, Seltzer \& Belitsky, 1974). In some of these instances the short-term hormone effects have been established as being directly hepatic in perfusion experiments. Glucagon does not appear to exert a short-term action on the synthesis of FA de novo (Raskin, McGarry \& Foster, 1974), although it can inhibit 'esterification' and export (Heimberg, Weinstein \& Kohout, 1969; Weinstein, Klausner \& Heimberg, I973; Weinstein et al. 1974). Long-term control of lipogenesis by insulin or glucagon can occur through enzyme induction, and probably reflects direct hormone actions on the liver.

The roles of hormones in glyceride dynamics and FA interconversions are obscure. A liver TG-lipase (triacylglycerol lipase; $E C$ 3.1.1.3) has been characterized (Kaplan \& Teng, I97I), but its 'hormone-sensitivity', unlike that of the adipose tissue enzyme, has not been clarified. The putative action of glucagon on lipolysis has not been satisfactorily established and is insensitive. Direct, short-term actions of insulin have not been fully clarified, but may include effects on desaturation (Salmon \& Hems, 1975). It is perhaps unlikely that insulin exerts important shortterm direct actions on lipid metabolism in the liver, as there is no glucagon effect (for insulin to 'de-inhibit'), and no insulin effect on glycogen synthesis (Whitton \& Hems, 1975).

\section{Bioenergetics of glyceride synthesis}

Flatt ( 1970 ) has pointed out that FA synthesis from glucose tends to generate a small amount of spare NADH, which could support ATP synthesis. Broadly, this reflects the role of the pyruvate dehydrogenase reaction, which allows two carbon atoms of glucose to be completely oxidized during reductive biosynthesis which consumes the other four atoms. More generally, this proposition may be restated: that glyceride synthesis from glucose is almost exactly 'self-supporting', in regard to reducing-equivalent provision, and ATP requirement. In liver, four extra aspects are relevant: (I) glycogen is a major precursor of FA (Salmon et al. 1974), and 
pyruvate derived from glycogen-glucose produces one extra ATP compared to glucose (but one less ATP than glucose which converts to pyruvate via glycogen); (2) lactate is also a major precursor (Salmon et al. 1974) which again produces 2 mol NADH/acetyl unit, but no ATP during conversion to pyruvate; (3) desaturation of newly-synthesized FA is faster than in adipose tissue (Elovson, 1965) (this would spare reducing equivalents, perhaps for oxidative phosphorylation, as NADH and NADPH can mutually transfer hydrogen in cytoplasm (Krebs \& Veech, 1969)); (4) $S n$-glycero-3-phosphate arises partly from glycerol, consuming I mol ATP/mol TG. If acyl-CoA can be formed from newly synthesized FA (e.g. by acyl transfer), then acyl transfer to glycerol requires no further ATP, beyond that for FA synthesis. However, other reactions of 'complex lipid' metabolism (e.g. in PL biosynthesis) require ATP (or other triphosphates).

Over-all, these considerations show that glyceride synthesis from all precursors can be self-supporting, in all chemical respects. The significance of this in control of glyceride synthesis, e.g. in obesity, is not clear.

\section{Nutritional aspects of hepatic glyceride metabolism}

Hepatic glyceride metabolism is inextricably linked with dietary events, e.g. synthesis and export are enhanced in obesity (Birkenhager \& Tjabbes, 1969) or on a high-carbohydrate intake (Schonfeld \& Pfleger, 1971; Park, Marai \& Mookerjea, 1972; Waddell \& Fallon, 1973; Olevsky, Farquhar \& Reaven, 1974; Romsos \& Leveille, 1974) and diminished in malnutrition or starvation. The 'fatty liver' (signifying TG accumulation) commonly has a nutritional origin, e.g. from alcoholism or dietary deficiencies (Lieber, Spritz \& de Carli, 1969; Lyman, Giotas, Medwadowski \& Miljanich, 1975). The nature of dietary fat is relevant; thus palmitate tends to produce fattier - livers than stearate (Lands, 1965). The explanations for fatty liver are complex, often including components of both excessive synthesis and impaired export, and are conspicuous for the absence of credible detail.

Obesity, a state in which there are inherent metabolic alterations (Hems, 1973), is the major nutritional disorder in the developed countries. In genetically obese mice there is enhanced export and synthesis of hepatic TG (Salmon \& Hems, 1973), partly as a result of increased de novo FA synthesis (Hems et al. 1975). Although insulin appears to be implicated (Loten, Rabinowitch \& Jeanrenaud, 1974), the full explanation for these changes in obesity is not known. They are associated with enhanced turnover of FFA and glycerol in plasma (Elliott et al. 1974), despite diminished rates of hepatic ketogenesis (Elliott et al. 1974) and normal concentrations of FFA in blood (Abraham, Dade, Elliott \& Hems, 1971). These events closely resemble those of human obesity.

The processes of 'complex lipid' metabolism exhibit subtle responses to dietary changes, e.g. of carbohydrate (Park et al. 1972; Fallon et al. 1975), or essential FA deficiency (Allman \& Gibson, 1965). Again, changes of this type are clearly implicated in the nutritional responses of hepatic glyceride synthesis, but the details are obscure. 
I thank the Wellcome Trust for generous support of the work on genetically obese mice, and my colleagues, particularly Dr D. M. W. Salmon, for much helpful discussion.

\section{REFERENCES}

Abou-Issa, H. M. \& Clelland, W. W. (1968). Biochim. biophys. Acta 176, 692.

Abraham, R. R., Dade, E., Elliott, J. A. \& Hems, D. A. (1971). Diabetes 20, 535.

Actis-Dato, S. M., Catala, A. \& Brenner, R. R. (1972). Lipids 8, I.

Akesson, B. (1970). Biochim. biophys. Acta $218,59$.

Akesson, B., Elovson, J. \& Arvidson, G. (1970). Biochim. biophys. Acta 248, I.

Allman, D. W. \& Gibson, D. M. (1965). Y. Lipid Res. 6, 51 .

Balasse, E. O., Bier, M. D. \& Havel, R. J. (1972). Diabetes $21,280$.

Bar-On, H., Roheim, P. S., Stein, O. \& Stein, Y. (1971). Biochim. biophys. Acta 248, 1.

Birkenhager, J. C. \& Tjabbes, T. (1969). Metabolism 18, 833.

Brenner, R. R. (1971). Lipids 6, 567.

Brett, D., Howling, D., Morris, L. J. \& James, A. T. (1971). Archs Biochem. Biophys. 143, 535 .

Chapman, M. J., Mills, G. L. \& Taylaur, C. E. (1973). Biochem. f. 131. 177.

Coniglio, J. G. \& Cate, D. L. (1958). f. biol. Chem. 232, 36r.

Dawson, R. M. C. (1966). Essays in Biochemistry, vol. 2, p.69. London: Academic Press.

De Gomes Dumm, I. N. T., De Alañiz, M. J. T. \& Brenner, R. R. (1970). F. Lipid Res. I1, 96

De Tomas, M. E., Peluffo, R. O. \& Mercuri, O. (1973). Biochim. biophys. Acta 306, 149.

Di Augustine, R. P., Schaefer, J. M. \& Fouts, J. R. (1973). Biochem. F. 132, 323.

Eaton, R. P., Berman, M. \& Steinberg, D. (1969). f. clin. Invest. 48, 1560.

Elliott, J. A., Dade, E., Salmon, D. M. W. \& Hems, D. A. (1974). Biochim. biophys. Acta 343, 307.

Elovson, J. (1965). Biochim. biophys. Acta 106, 291.

Fallon, H. J., Barwick, J., Lamb, R. G. \& Van den Bosch, H. (1975). F. Lipid Res. 16, 107.

Flatt, J. P. (1970). Y. Lipid Res. 1x, 131.

Fukazawa, T., Privett, O. S. \& Takahashi, Y. (1971). Lipids 6, 388.

Fulco, A. J. (1974). A. Rev. Biochem. 43, 215.

Gatt, S. \& Barenholz, Y. (I973). A. Rev. Biochem. 42, 6r.

Gregory, D. H., Vlahcevic, D., Schatzki, P. \& Swell, L. (1975). f. clin. Invest. 55, 105.

Groot, P. H. E., Van Loon, C. M. I. \& Hulsmann, W. C. (1974). Biochim. biophys. Acta 337, I.

Gurr, M. I. (1974). In MTP International Review of Science, vol. 4 Biochemistry of Lipids, p. I8I [T. W. Goodwin, editor]. London: Butterworths.

Heimberg, M., Weinstein, I. \& Kohout, M. (1969). F. biol. Chem. 244, 5131.

Heimberg, M. \& Wilcox, H. G. (1972). f. biol. Chem. $247,875$.

Hems, D. A. (1973). In Getting the Most Out of Food, vol. 8, p. 6r. London: Van den Berghs \& Jurgens Led.

Hems, D. A., Rath, E. \& Verrinder, T. (1975). Biochem. F. 150, 167.

Hinsch, W. \& Seubert, W. (1975). Eur. $\mathcal{Y}$. Biochem. 53, 437.

Holloway, C. T. \& Holloway, P. W. (1975). Archs Biochem. Biophys. 167, 496.

Hosaka, K., Yamashita, S. \& Numa, S. (I975). Y. Biochem., Tokyo 77, 501 .

Inkpen, C. A., Harris, R. A. \& Quackenbush, F. W. (1969). $\mathcal{~ f . ~ L i p i d ~ R e s . ~ 1 0 , ~} 277$.

Jones, P. D., Holloway, P. W., Peluffo, R. O. \& Wakil, S. J. (I969). J. biol. Chem. 244, 744.

Kaplan, A. \& Teng, M-H. (197I). Y. Lipid Res. 12, 324.

Kirk, C. J., Verrinder, T. R. \& Hems, D. A. (1975). Biochem. Soc. Trans. 3, 515.

Klausner, H. \& Heimberg, M. (1967). Am. F. Physiol. 212, 1236.

Kohout, M., Kohoutova, B. \& Heimberg, M. (1971). F. biol. Chem. 246, 5067.

Krebs, H. A. \& Veech, R. L. (1969). Adv. Enz. Regul. 7, 397.

Kuksis, A. (1972). Progr. Chem. Fats 12, I.

Lamb, R. G. \& Fallon, H. J. (1970). F. biol. Chem. 245, 3075.

Landriscina, C., Gnoni, G. V. \& Quagliariello, E. (1970).' Biochim. biophys. Acta 202, 405.

Lands, W. E. M. (1965). A. Rev. Biochem. 34, 313.

Lieber, C. S., Spritz, N. \& de Carli, L. (I969). F. Lipid Res. 10, 283.

Lippel, K., Robinson, J. \& Trams, E. (1970). Biochim. biophys. Acta 206, 173.

Lloyd-Davies, M. \& Brindley, D. N. (1973). Biochem. Soc. Trans. 1, 436.

Loten, E. G., Rabinowitch, A. \& Jeanrenaud, B. (1974). Diabetologia 10, 45.

Lyman, R. L., Giotas, C., Medwadowski, B. \& Miljanich, P. (1975). Lipids 10, 157.

McGarry, J. D. \& Foster, D. W. (1972). Metabolism 21, 471.

McGarry, J. D. \& Foster, D. W. (1973). J. clin. Invest. 52, 877 . 
McGarry, J. D. \& Foster, D. W. (1974). F. biol. Chem. 249, 7984.

McGarry, J. D., Meier, J. M. \& Foster, D. W. (1973). F. biol. Chem. 248, 270.

Mangiapane, E. H., Lloyd-Davies, K. A. \& Brindley, D. N. (1973). Biochem. F. 134, 103.

Mercuri, D., Peluffo, R. O. \& De Tomas, M. E. (1974). Biochim. biophys. Acta 369, 264.

Mishkin, S., Stein, L., Gatmaitan, Z. \& Arias, I. M. (1972). Biochem. biophys. Res. Commun. 47, 997.

Nakagawa, M. \& Uchiyama, M. (1969). f. Biochem., Tokyo 65, 673.

Nestel, P. I. \& Steinberg, D. (1963). F. Lipid Res. 4, 461.

Nugteren, D. H. (1965). Biochim. biophys. Acta 106, 280.

Okuyama, H., Yamada, K \& Ikezawa, H. (1975). J. biol. Chem. 250, 1710.

Olevsky, J. M., Farquhar, J. W. \& Reaven, G. M. (1974). Am. J. Med. 57, 551.

Oshino, N. (1972). Biochim. biophys. Acta 149, 378.

Oshino, N. \& Sato, R. (1972). Archs Biochem. Biophys. 149, 369.

Park, C. E., Marai, E. \& Mookerjea, S. (1972). Biochim. biophys. Acta 270, 50.

Parkes, J. G. \& Thompson, W. (1973). Biochim. biophys. Acta 306, 403.

Podack, E. R., Lakomek, M., Saathoff, G. \& Seubert, W. (1974). Eur. F. Biochem. 45, 13.

Raskin, P., McGarry, J. G. \& Foster, D. W. (1974). J. biol: Chem. 249, 6029.

Reitz, R. C., Lands, W. E. M., Christie, W. W. \& Holman, R. T. (1968). J. biol. Chem. 243, 2242.

Romsos, D. R. \& Leveille, G. A. (1974). Biochim. biophys. Acta 360, I.

Rous, S. (1971). Adv. Lipid Res. 9, 73.

Salmon, D. M. W., Bowen, N. L. \& Hems, D. A. (1974). Biochem. Y. 142, 611.

Salmon, D. M. W. \& Hems, D. A. (1973). Biochem. $\mathscr{F}$. 136, 551.

Salmon, D. M. W. \& Hems, D. A. (1975). Biochem. Soc. Trans. 3, 510.

Sanchez, M., Nicholls, G. D. \& Brindley, D. N. (1973). Biochem. J. 132, 697.

Sarzala, M. G., Van Golde, L. M. G., de Kruyff, B. \& van Deenen, L. L. M. (1970). Biochim. biophys. Acta 202, 106.

Schonfeld, G. \& Pfleger, B. (1971). F. Lipid Res. 12, 614.

Seubert, W. \& Podack, E. R. (1973). Mol. cell. Biochem. 1, 29.

Sinclair, A. J. (1974). Lipids, 9, 809.

Singer, P., Gnauck, G., Honigman, G., Stolz, P., Schliack, V., Kettler, L.-H., Buntrock, P. \& Thoelke, H. (1974). Diabetologia ro, 455.

Solberg, H. E. (1974). Biochim. biophys. Acta 360, 101.

Stein, Y. \& Stein, O. (1974). Horm. Metab. Res. Suppl. no. 4, 16.

Stoffel, W. \& Ach, K. L. (1964). Hoppe-Seyler's Z. physiol. Chem. 337, 123.

Strittmatter, P., Spatz, L., Corcoran, D., Rogers, M. J., Setlow, B. \& Redline, R. (1974). Proc. natn. Acad. Sci. U.S.A. 71, 4565.

Topping, D. L. \& Mayes, P. A. (1972). Biochem. I. 126, 295.

Van Golde, L. M. G., Raben, J., Batenburg, J. J., Fleischer, B., Zambrano, F. \& Fleischer, S. (1974). Biochim. biophys. Acta 380, 179.

Van Harken, D. R., Dixon, C. W. \& Heimberg, H. (1969). f. biol. Chem. 244, 2278.

van Tol, A. \& Hulsmann, W. C. (1970). Biochim. biophys. Acta 223, 416.

Waddell, M. \& Fallon, H. J. (1973). \%. clin. Invest. 52, 2725.

Wadke, M., Brunengraber, H., Lowenstein, J. M., Dolhun, J. J. \& Arsenault, G. P. (1973). Biochemistry, Easton 12, 2619.

Weinstein, I., Klausner, H. A. \& Heimberg, M. (1973). Biochim. biophys. Acta 296, 300.

Weinstein, I., Seltzer, M. \& Belitsky, R. (1974). Biochim. biophys. Acta 348, 14.

Whitton, P. D. \& Hems, D. A. (1975). Biochem. F. 150, 153.

Wilcox, H. C., Dishmon, G. \& Heimberg, M. (1968). f. biol. Chem. 243, 666.

Wood, R. \& Harlow, R. D. (1969). Archs Biochem. Biophys. 131, 495.

Yamashita, S., Nakaya, N., Miki, Y. \& Numa, S. (1975). Proc. natn. Acad. Sci. U.S.A. 72, 600. 